\section{АВТОНОМНЫЙ ЛАЗЕРНЫЙ ИЗМЕРИТЕЛЬ КОЛЕБАНИЙ}

\section{ДАВЛЕНИЯ}

\author{
Г. И. Долгих, С. С. Будрин, В.А.Швеи, С. В.Яковенко \\ Федерапьное государственное бюджетное учрежде- \\ ние науки \\ Тихоокеанский Океанологический институт \\ им. В.И.Ильичева \\ Дальневосточного отделения Российской академии \\ наук; \\ Школа естественных наук Федерального государ- \\ ственного автономного образовательного учреж- \\ дения высшего профессионального образования \\ "Дальневосточный федеральный университет".
}

\section{Описан автономный лазерный измеритель} колебаний давления для использования под водой. Прибор может быть использован вдали от береговой черты, поскольку предусмотрена возможность его автономной работы, для чего был разработан подключаемый к прибору контейнер, снабженный элементами питания, системой сбора и накопления информации. Наличие датчиков снаружи и внутри измерителя позволяет проводить коррекцию записи вариаций давления в зависимости от изменения температуры интерферометра и забортной воды, а дополнительный интерфейс электрического питания и порт данных позволяет подключать внешние устройства для расширения функционала прибора.

Статья поступила в редакцию 28.03.2019 Статья принята к публикации 15.04.2019

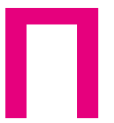
ри изучении различных гидрофизических процессов, природы их возникновения и развития существенное значение имеют технические характеристики установок. Стремление увеличить чувствительность, расширить рабочий частотный диапазон привело к тому, что интерферометры, ранее не использовавшиеся в подводных приборах из-за громоздкости и сложной эксплуатации, появились в этой области измерительной техники. Современные достижения по созданию компактных моделей частотно-стабилизированных лазеров, электроники, трехмерного моделирования позволили создать приборы этого типа, не выходя за рамки допустимых эксплуатационных характеристик по весу,

\section{AUTONOMOUS LASER PRESSURE FLUCTUATION METER}

\author{
G. I. Dolgikh, S. S. Budrin, V.A. Shvets, S. V. Yakovenko \\ Federal State Budgetary Institution of Science \\ V.I.Ilyichev Pacific Oceanological Institute \\ Far Eastern Branch of the Russian Academy of Sciences; \\ School of Natural Sciences of the Federal State Autono- \\ mous Educational Institution of Higher Professional \\ Education "Far Eastern Federal University"
}

An autonomous laser pressure meter for underwater use has been described. The use of optical measurement methods based on interference methods, optimization of the device design based on existing design experience, allowed us to develop and create a compact device that has a high accuracy of measuring pressure fluctuations in a wide frequency range. The device can be used away from the coastline, since it provides for the possibility of its autonomous operation, for which a container connected to the device, equipped with batteries, a system for collecting and storing information, was developed. The sensors outside and inside the meter allow for correction of the recording of pressure variations depending on changes in the temperature of the interferometer and seawater, and an additional electrical power interface and data port allow you to connect external devices to expand the functionality of the instrument.

Article received for editing 28.03.2019 Article accepted for publication 15.04.2019

W hen studying various hydrophysical processes, the nature of their occurrence and development, technical characteristics of installations are essential. The strive to increase the sensitivity, to expand the working frequency range led to the emergence of interferometers in this area of measurement technology, which have not been previously used in underwater instruments because of their bulkiness and difficult operation. Modern advances in the creation of compact models of frequency-stabilized lasers, electronics, and three-dimensional modelling have made it possible to create instruments of this type without going beyond the permissible operating characteristics in terms of weight, dimensions, and rational use pos- 
габаритам и разумным возможностям использования. В результате лазерно-интерференционный прибор для измерения вариаций давления получает широкие возможности по чувствительности, большому частотному диапазону, присущему интерферометру, включенному в его конструкцию. Опыт создания приборов на основе лазерноинтерференционных методов получен нами ранее при работе над различными измерителями физических параметров геосфер [1-3]. Эти устройства измеряют в инфразвуковом и звуковом диапазонах с высокой точностью на уровне фоновых шумов. Это такие устройства, как лазерные деформографы, лазерные нанобарографы, лазерные измерители вариаций давления гидросферы, разработанные соответственно для измерения микросмещений верхнего слоя земной коры, вариаций атмосферного и подводного давления. При использовании этих приборов были получены новые данные о взаимодействии геосфер. Например, было установлено, что цуги волн давления в водной среде с периодами, лежащими в диапазоне 7-13 мин, вызваны подобными же цугами волн в атмосферном давлении, а не короткопериодными внутренними морскими волнами [4]. Комплексное использование этих устройств позволяет охватить большой спектр научных задач, связанных с изучением процессов взаимодействия геосфер. Для этого приборы объединяются в измерительные полигоны [5], с тем чтобы проводить совместный мониторинг параметров геосфер.

Применение лазерноинтерференционных измерителей вариаций давления [6] в научных исследованиях позволило накопить большой опыт работы с такими устройствами. Были даже созданы модификации с использованием разных источников излучения и компоновки прибора [7]. Но также был выявлен ряд негативных особенностей в эксплуатации этих приборов. Среди них следует отметить: 1) большие геометрические размеры и массу, что приводит к неудобству эксплуатации sibilities. As a result, a laser-interference device for measuring pressure variations has wide possibilities in sensitivity, a large frequency range inherent in the interferometer incorporated in its construction. The experience of creating devices based on laserinterference methods was obtained by us earlier when working on various measures of the physical parameters of the geospheres [1-3]. These devices measure in the infrasound and sound ranges with high accuracy at the level of background noise. These are devices such as laser strainmeters, laser nanobarographs, laser meters of pressure variations in the hydrosphere, developed accordingly to measure micro-displacements of the upper crustal layer, variations in atmospheric and underwater pressure. When using these devices, new data on the interaction of geospheres was obtained. For example, it was found that pressure wave trains in an aqueous medium with periods lying in the range of 7-13 min are caused by similar wave trains at atmospheric pressure, rather than short-period internal sea waves [4].

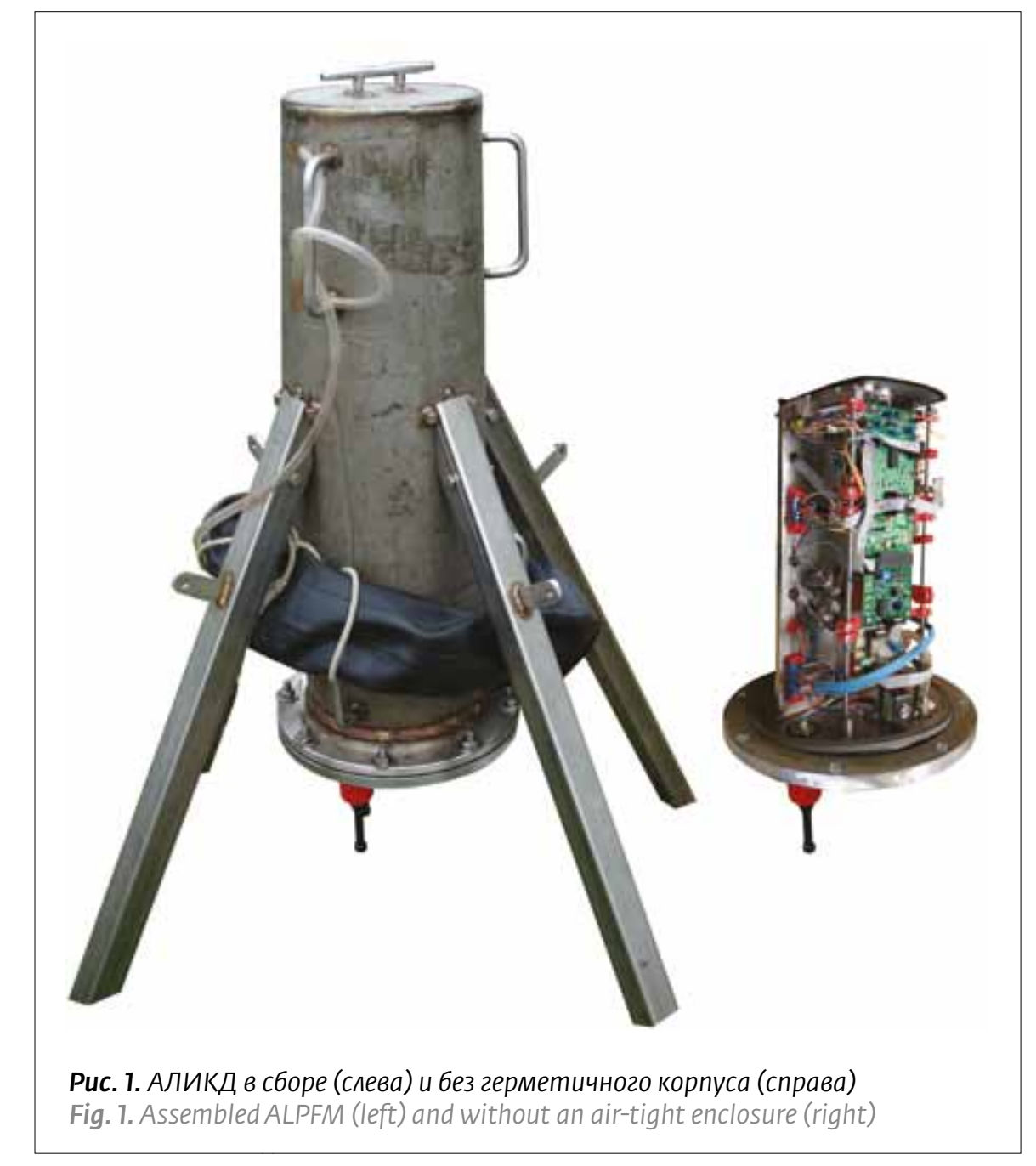


и неустойчивости интерференционной картины, 2) влияние изменения забортной температуры на показания интерферометра, 3) невозможность автономной работы, 5) невозможность подключения внешнего оборудования .

В связи с указанными недостатками на основе конструкции лазерного измерителя вариаций давления гидросферы был создан новый прибор автономный лазерный измеритель колебаний дав ления (АЛИКД), рис. 1.

Проверенный во многих приборах коллектива принцип действия, основанный на интерферометре Майкельсона, построенном по модифици рованной схеме неравноплечего типа, использо ван и здесь. Оптико-механическая схема прибора и принцип его действия схематически показаны на рис. 2.

В качестве источника излучения используется газовый гелий-неоновый частотно стабилизированный лазер MellesGriot, компактная модель.

Одно плечо интерферометра является эталонным. Луч, который распространяется по другому плечу, проходит через зеркало, установленное на мембране в крышке прибора. Внешняя сторона мембраны 3 соприкасается с водой, и этот луч является, таким образом, измерительным. Про странственное сведение попадающих на делительную пластину 6 обоих лучей (после их прохождения по своим оптическим путям) позволяет получить интерференционную картину переменной яркости, обусловленную изменением разно сти хода лучей. Изменение яркости регистриру ется фотоприемником 2 системы регистрации 7, которая формирует управляющий сигнал на компенсацию разности хода лучей. Этот же сигнал является выходным, и он же подается на один из пьезокерамических элементов 5 для возврата интерференции на экстремум. На второй элемент подается пробный (или поисковый) сигнал, кото рый представляет собой гармонические колебания, обеспечивающие правильную систему экстремального регулирования.

В приборе применяется система компенсации гидростатического давления. Она необходима для выравнивания давления по обе стороны от мембраны, чтобы привести ее перед измерениями в нейтральное положение. При погружении прибора по команде открывается электромагнитный клапан, который пропускает воздух из специаль ной резиновой емкости в камеру небольшого объ ема между мембраной и основным пространством корпуса, отделенную от него прозрачным гермоок-

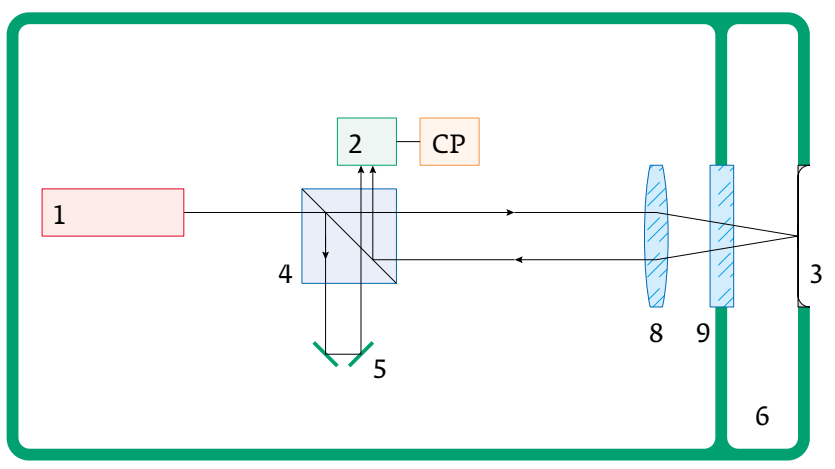

10

Puc. 2. Оптико-механическая схема прибора: 1 - источник излучения; 2 - фотоприемник; 3 - мембрана с закрепленным на ней зеркалом; 4 - делительный кубик; 5 - пьезокерамические цилиндры компенсации и пробного сигнала; 6 - камера компенсации гидростатического давления; 7- система регистрации; 8 - собирающая пинза; 9 - гермоокно; 10 - герметичный корпус

Fig. 2. Optical-mechanical device circuit: 7 - radiation source; 2 - photodetector; 3 - membrane with a fixed mirror; 4 - dividing cube; 5 - piezoceramic compensation and test cylinders; 6 hydrostatic pressure compensation chamber; 7 - registration system; 8 -collecting lens; 9 - thermo-window; 10 - air-tight enclosure

The integrated use of these devices allows you to cover a wide range of scientific problems related to the study of the processes of interaction of geospheres. To this end, the devices are combined into measuring polygons [5], in order to conduct joint monitoring of the parameters of geospheres.

The use of laser-interference measuring devices for pressure variations [6] in scientific research has made it possible to accumulate much experience with such devices. Modifications were even made using different sources of radiation and device layout [7]. But a number of negative features in the operation of these devices was also revealed. Among them are as follows: 1) large geometrical dimensions and mass, which leads to inconvenience of operation and instability of the interference pattern, 2) the effect of changes in the outside temperature on the interferometer readings, 3) inability to work autonomously, 5) inability to connect external equipment.

In connection with these drawbacks, based on the design of the laser meter of hydrosphere pressure variations, a new device was created: an autonomous laser pressure fluctuation meter (ALPFM), Fig. 1.

The principle of action, tested in many instruments of the facility, based on the Michelson interfer- 
ном 9. По окончании погружения клапан закрывается до начала измерений. При подъеме прибора давление из компенсационной камеры стравливают обратно.

Оптическая скамья выполнена из нержавеющей стали, что в совокупности с расположенными по обеим сторонам ребрами усиления и стальными растяжками с верхней стороны позволяет получить большую жесткость конструкции. Источник излучения располагается под оптической скамьей, откуда луч через отверстие выводится с помощью перископической системы зеркал. Блоки питания прибора располагаются в отдельном объеме от оптико-механической части внутри корпуса прибора.

Среди дополнительного оборудования аппаратурной части следует упомянуть наличие измерителей температуры. На оптической скамье интерферометра и снаружи прибора (в тонкостенном щупе-стержне, расположенном в районе мембраны) установлены датчики температуры на основе цифрового термометра DS18B20. Измерение температуры внутри прибора необходимо, поскольку вариации температуры могут вносить существенную погрешность в показания неравноплечего интерферометра. Разрешающая спо- ometer, constructed according to a modified scheme of unequal-arm type, is applied here. The opticalmechanical scheme of the device and the principle of its operation are shown schematically in Fig. 2

A helium-neon frequency-stabilized laser MellesGriot, a compact model, is used as a radiation source.

One "arm" of the interferometer is a reference. A beam that propagates along the other "arm" passes through a mirror mounted on a membrane in the lid of the device. The outer side of the membrane 3 is in contact with water and this beam is thus measuring. The spatial convergence of both beams falling onto the dividing plate 6 (after passing through their optical paths) makes it possible to obtain an interference pattern of variable brightness caused by the change in the path difference of the beams. The change in brightness is recorded by the photodetector 2 of the registration system 7 , which generates a control signal to compensate for the difference in the path of the beams. The same signal is output and it is also fed to one of the piezoceramic elements 5 to return the interference to the extremum. A "test" (or search) signal is fed to the second element, which is a harmonic oscillation, providing the correct system of extreme regulation.

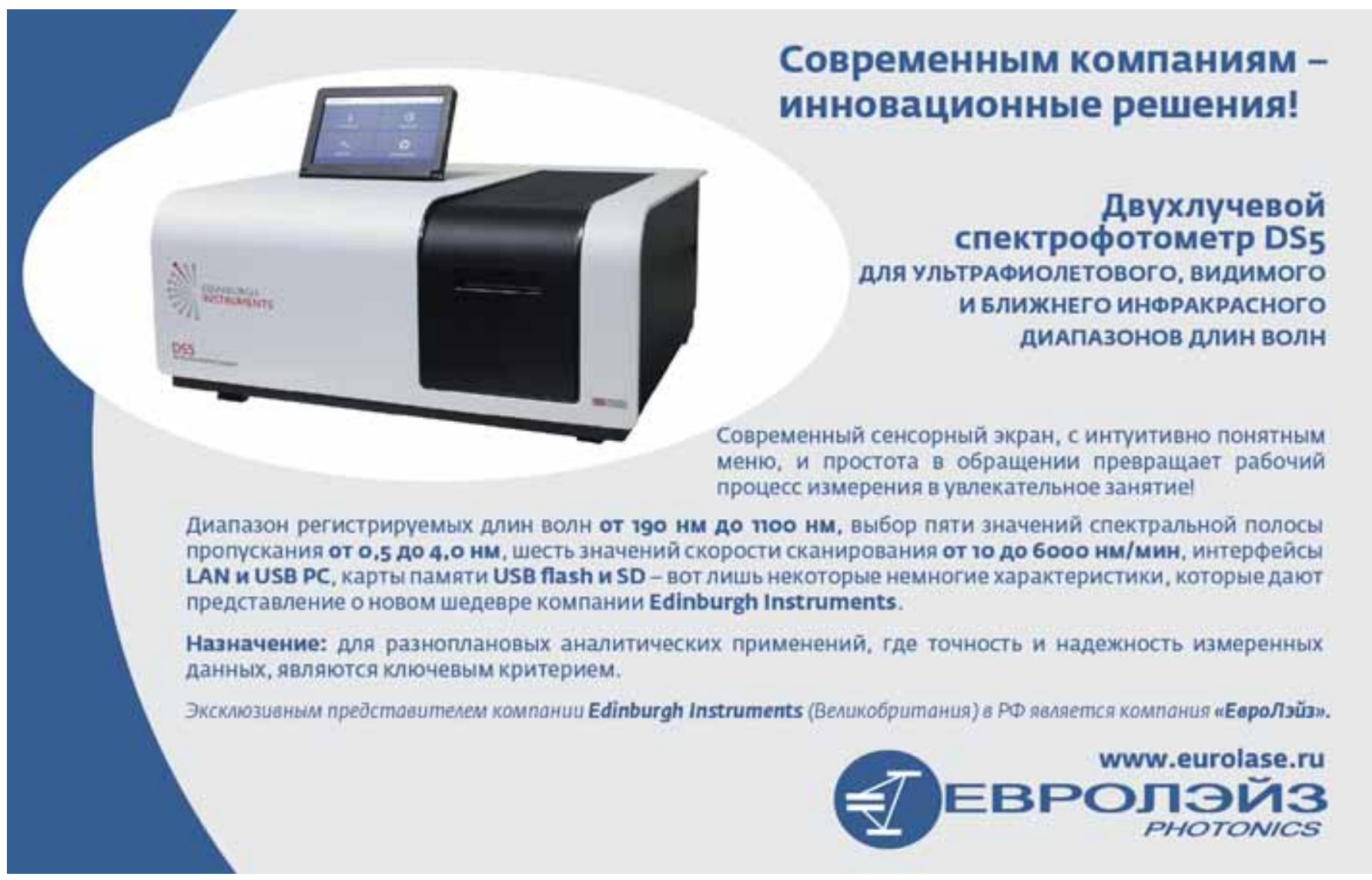


собность датчика при использовании 12-битной платы аналого-цифрового преобразователя (АЦП) составляет $0,0625^{\circ} \mathrm{C}$.

Для грубого измерения забортного давления (например, для определения глубины установки прибора) предусмотрена возможность установки датчика давления. Для этого в крышке при бора имеется гермо-штуцер для установки тензопреобразователя избыточного давления D0.4-T. Предельно измеряемое давление датчика равно 0,8 МПа, что соответствует глубине погружения -80 м, разрешающая способность составляет 90 Па, т.е. $0,01 \%$ от диапазона измеряемого давления. При необходимости работы на глубине более $80 \mathrm{M}$ предусмотрена возможность быстрой замены дат чика давления. Для согласования датчика с измерительной и регистрирующей частями оборудования используется измерительный усилитель с переменным коэффициентом усиления в диапазоне 5-4001.

На крышке прибора установлен герметичный разъем, предназначенный для дополнительного оборудования. Это универсальный интерфейс, на который выделено отдельное питание и линия передачи данных. В частности, измеритель может работать совместно с флуориметром ECO FL, предназначенным для определения биологических характеристик воды, в частности содержания хлорофилла-а. Этот датчик позволяет проводить измерения в диапазоне 0-125 мкг/л с разрешением 0,02 мкг/л. Могут также быть подключены дат чики глубины, гидрофоны, модуль радиосвязи для телеметрии и отправки предварительных данных и прочие устройства.

В работе интерферометра используется система регистрации интерференционного измерителя вариаций давления [8] с некоторыми модификациями. Изменения коснулись улучшения характе ристик цифро-аналогового преобразователя (ЦАП): теперь установлена модель 14 бит. В системе регистрации используется принцип удержания интер ференции на уровне максимальной яркости. Это обеспечивается рабочим органом системы регистрации - компенсирующей пьезокерамикой, которая перемещает свой незакрепленный конец с установленным на нем зеркалом, с постоянной скоростью, удерживая интерференцию на экстремуме. Для определения направления смещения от положения экстремума вторая пьезокерамика вводит в оптический сигнал искусственное гармо ническое возмущение с частотой 100 кГц - сигнал раскачки, являющийся пробным или поисковым. Для рассматриваемой системы с постоянной ско-
The instrument uses a hydrostatic pressure compensation system. It is necessary to equalize the pressure on both sides of the membrane in order to bring it to the neutral position before measurements. When the device is immersed, a solenoid valve is opened upon command, which passes air from a special rubber container into a small volume chamber between the membrane and the main body space, separated by a transparent pressure window 9 . When the diving is finished, the valve closes before the measurements start. When the device is lifted, the pressure from the compensation chamber is relieved.

The optical bench is made of stainless steel, which, together with the reinforcement ribs located on both sides and steel stretch marks on the upper side, allows for greater rigidity of the structure. The radiation source is located under the optical bench, from where the beam through the hole is output using a periscopic system of mirrors. The power supply units of the device are located in a separate volume from the optical-mechanical part inside the device case.

It is necessary to mention the temperature meters among the additional equipment of the hardware part. Temperature sensors based on a DS18B20 digital thermometer are installed on the optical bench of the interferometer and on the outside of the instrument (in a thin-walled probe rod located in the area of the membrane). Measuring the temperature inside the instrument is necessary, since temperature variations can introduce a significant error in the readings of the non-equal interferometer. The resolution of the sensor when using a 12-bit analogue-to-digital converter (ADC) board is $0.0625^{\circ} \mathrm{C}$.

For a rough measurement of outboard pressure (e.g., to determine the depth of installation of the device), it is possible to install a pressure sensor. For this purpose, there is a pressure-tight fitting in the cover of the device for installing an overpressure strain meter D0.4-T. The maximum measured pressure of the sensor is $0.8 \mathrm{MPa}$, which corresponds to an immersion depth of $\sim 80 \mathrm{~m}$, the resolution is 90 $\mathrm{Pa}$, i.e. $0.01 \%$ of measured pressure range. If it is necessary to work at a depth of more than $80 \mathrm{~m}$, it is possible to quickly replace the pressure sensor. For matching the sensor with the measuring and recording parts of the equipment, a measuring amplifier with a variable gain in the range of $5 \div 4001$ is used.

On the cover of the device there is an air-tight connector for additional equipment. This is a universal interface with a separate power supply and data line. In particular, the meter can work in con- 
ростью перемещения рабочего органа обратной связи (компенсирующей пьезокерамики) связь между максимальной скоростью $v$ перемещения рабочего органа системы регистрации, частотой $f$ пробного (поискового) сигнала, длиной волны $\lambda$ излучения лазера и разрядностью $N$ ЦАП, можно описать выражением:

$$
v=\frac{\lambda f}{2^{N}} .
$$

Из (1) следует, что с повышением разрядности необходимо повышать и частоту поискового сигнала. В разработанном приборе частота поискового сигнала составляет 100 кГц, что в четыре раза выше, чем в ранее созданных системах. При условии, что динамический диапазон усилителя, управляющего рабочим органом системы регистрации, не уже, чем у ЦАП, максимальная точность измерения перемещений мембраны измерителей давления составляет $0,75 \lambda /\left(2^{N-1}\right)$ или $0,06 \mathrm{Hм}$.

Давление, которое регистрирует измеритель вариаций давления гидросферы, оборудованный описанной регистрирующей системой, можно рассчитать по формуле, описывающей поведение закрепленной по краям плоской мембраны [9]:

$$
P=\frac{\Delta l \cdot 16 h^{3} E}{3\left(1-\sigma^{2}\right) R^{4}} .
$$

Здесь $\Delta l$ - смещение мембраны; $h$ - толщина мембраны; E - модуль Юнга; $\sigma$ - коэффициент Пуассона; R - радиус мембраны. В измерителе могут быть использованы мембраны, изготовленные из листа нержавеющей стали толщиной 0,1 ; 0,5; 1; 2 мм. В испытаниях использована мембрана толщиной 1 мм. Подставляя в (2) следующие значения: $R=5 \mathrm{~cm}, h=1 \mathrm{~mm}, E=2,1 \cdot 10^{11} \mathrm{H} / \mathrm{M}^{2}$, $\sigma=0,25$ и $\Delta l=0,06$ нм, получим, что разрешение измерителя по давлению составляет $\mathrm{P}=11,5$ мПа. При этом, с точки зрения частотных характеристик, система способна регистрировать вариации давления в диапазоне частот от самых низких (близких к нулевым) до 1000 Гц.

Передача показаний прибора на береговую станцию по кабельной линии удобна лишь при небольших дистанциях от берега, подготовленной инфраструктуре, береговой черте без крутых склонов со свободным доступом к этой черте. Все это сильно усложняет установку и эксплуатацию системы, а проведение измерений на дистанциях более 500 м от берега так и вовсе становится на практике тяжело выполнимой задачей. Поэтому обеспечение возможности автономной работы junction with the ECO FL fluorometer, designed to determine the biological characteristics of water, in particular, the content of chlorophyll-a. This sensor allows for measurements in the range of $0 \div 125$ $\mu \mathrm{g} / \mathrm{l}$ with a resolution of $0.02 \mu \mathrm{g} / \mathrm{l}$. Depth sensors, hydrophones, a radio module for telemetry and sending preliminary data, and other devices can also be connected.

In the work of the interferometer, a system is used to record the interference meter of pressure variations [8] with some modifications. The changes affected the improvement of the characteristics of the digital-to-analogue converter (DAC), the 14-bit model is now installed. The registration system uses the principle of retaining interference at the maximum brightness level. This is provided by the working body of the registration system - compensating piezoceramics, which moves its unfixed end with a fixed mirror, at a constant speed, keeping the interference at the extremum. To determine the direction of displacement from the extremum position, the second piezoelectric ceramics introduces an artificial harmonic perturbation into the optical signal, with a frequency of $100 \mathrm{kHz}$ - a "buildup" signal, which is a test or a search signal. For the considered system with the constant speed of movement of the feedback body (compensating piezoceramics) between the maximum speed $v$ of movement of the recording system, the frequency $f$ of the test (search) signal, the wavelength $\lambda$ of laser radiation and the digit capacity N DAC can be described as follows:

$$
v=\frac{\lambda f}{2^{N}} .
$$

From (1) it follows that with increasing digit capacity, it is necessary to increase the frequency of the search signal. In the developed device, the frequency of the search signal is $100 \mathrm{kHz}$, which is four times higher than in previously created systems. Provided that the dynamic range of the amplifier controlling the working body of the recording system is not narrower than that of the DAC, the maximum measurement accuracy of the displacements of the diaphragm of the pressure meters is $0.75 \lambda /\left(2 \mathrm{~N}^{-1}\right)$ or $0.06 \mathrm{~nm}$.

The pressure recorded by the pressure variation meter of the hydrosphere, equipped with the described recording system, can be calculated using the formula describing the behaviour of the flat membrane fixed along the edges [9]:

$$
P=\frac{\Delta l \cdot 16 h^{3} E}{3\left(1-\sigma^{2}\right) R^{4}} .
$$


лазерно-интерференционного комплекса - необходимость. Однако, как показал практический опыт, переход на полностью автономную работу с размещением в корпусе прибора средств регистрации и источников питания оказался нецелесообразным. Ухудшать достигнутые характеристики веса и размера прибора означает усложнение эксплуатации, необходимость в использовании более крупных плавсредств и подъемных механизмов. Кроме того, при проведении измерений вблизи береговой черты, использование кабельной линии вполне оправданно отсутствием ограничений по энергопотреблению, продолжительностью времени работы, возможностью мгновенного получения любого объема информации, регистрируемой датчиками, упрощением телеметрии. Чтобы одновременно сохранить указанные преимущества и обеспечить возможность работы как с использованием кабельной линии, так и без нее был разработан контейнер автономизации (рис. 3).

В состав контейнера входят батареи питания (литий-ионная батарея электрического питания 4S мощностью 7965 Вт·ч), блоки согласования и стабилизации параметров электрических цепей, а также микрокомпьютер с твердотельным накопителем для записи информации, поступающей из прибора. Контейнер подключается к герморазъему прибора, который обычно используется для берегового кабеля. Время автономной работы прибора составляет более 6 суток, что с учетом значительности потребления энергии газовым лазером, системы регистрации, измерителями давления и температуры и системами связи, работающими на высоких частотах, является очень хорошим показателем. Были проведены успешные испытания автономной работы в течение

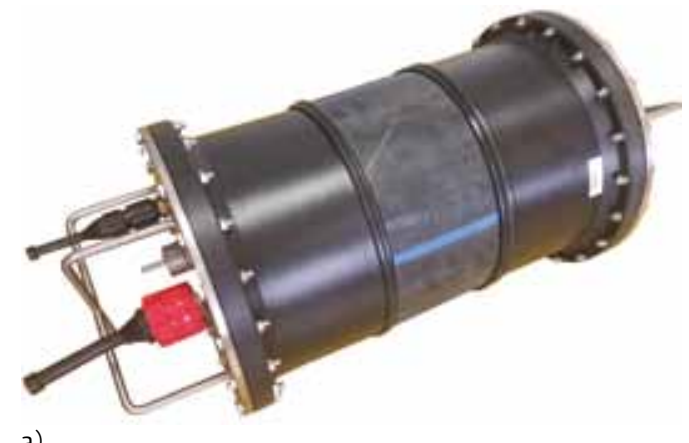

a)

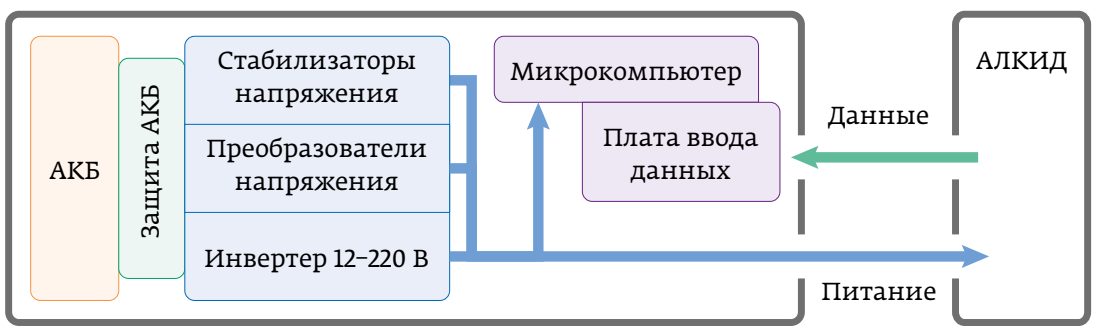

b)

Puс. 3. Контейнер автономизации: a) фото; b) принципиальная схема Fig. 3. Autonomation container: a) photo; b) schematic
Here, $\Delta l$ is the membrane displacement; $h$ is the membrane thickness; $E$ is Young's modulus; $\sigma$ is the Poisson's ratio; $\mathrm{R}$ is the radius of the membrane. Membranes made of stainless-steel sheet with a thickness of $0.1 ; 0.5 ; 1 ; 2 \mathrm{~mm}$. The membrane with a thickness of $1 \mathrm{~mm}$ was used in the tests. Substituting the following values into (2): $R=5 \mathrm{~cm}, h=1 \mathrm{~mm}$, $E=2.11011 \mathrm{~N} / \mathrm{m}^{2}, \sigma=0.25$ and $\Delta l=0.06 \mathrm{~nm}$, we get that

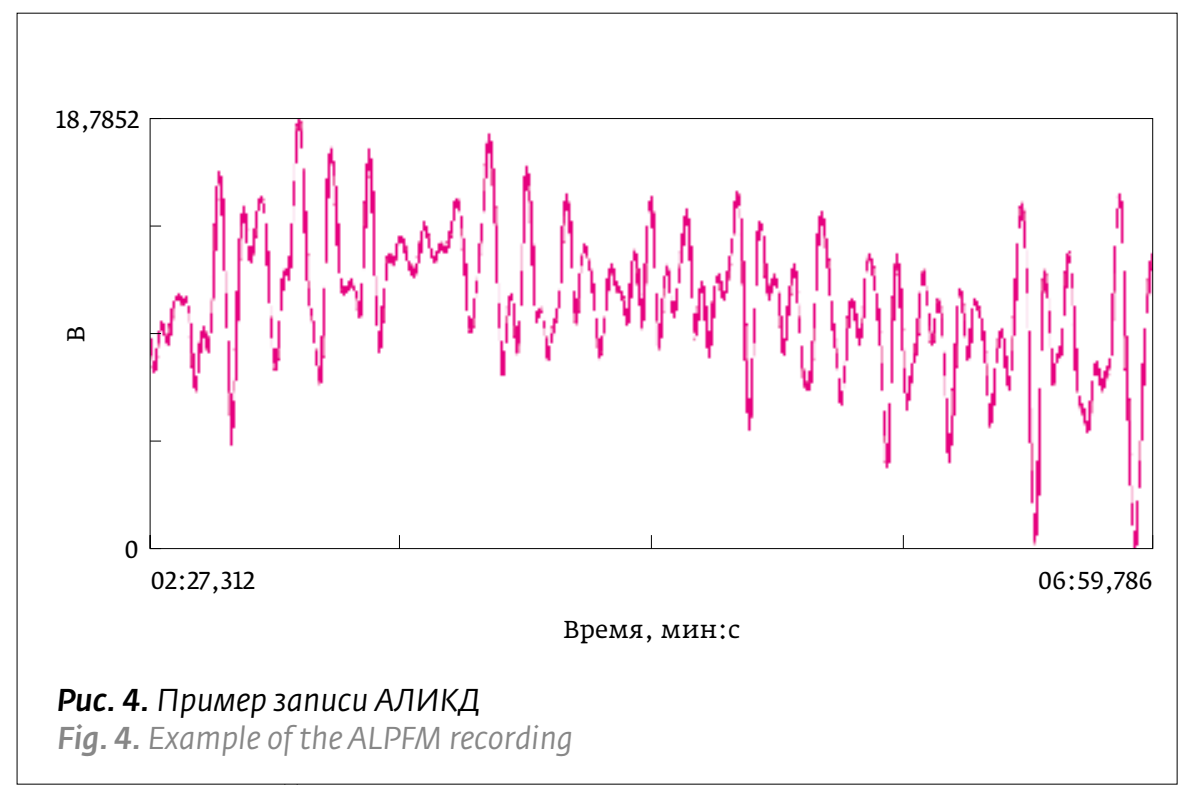


145 ч. На рис. 4 приведен участок записи, демонстрирующий колебания давления при ветровом волнении. По оси ординат - напряжение на выходе системы регистрации, пропорциональное измеряемому давлению. Коэффициент пересчета 0,25 В/Па. По оси абсцисс - время. Глубина установки прибора $12 \mathrm{M}$.

Установленные в приборе цифровые датчики температуры позволяют проводить корректировку показаний интерферометра с учетом вариаций температуры. Это важно, поскольку изменение температуры внутри прибора приводит к изменению длины эталонного плеча вследствие теплового расширения деталей интерферометра. Внешний датчик дает информацию о поле температуры снаружи прибора. В данной модели прибора требуется корректировка выходного сигнала системы регистрации интерферометра на $-3,305$ В на каждый шаг измерения термодатчика, т.е. на 0,0625 ${ }^{\circ} \mathrm{C}$. Значение напряжения было подобрано эмпирическим путем при проведении тестов. Функция коррекции показаний интерферометра была включена в программное обеспечение обработки измерений.

Испытания разработанного АЛИКД прошли успешно, и прибор может быть использован для the pressure meter resolution is $P=11.5 \mathrm{MPa}$. At the same time, in terms of frequency characteristics, the system is able to record pressure variations in the frequency range from the lowest (close to zero) to 1000 $\mathrm{Hz}$.

The transfer of the instrument readings to the coast station via a cable line is convenient only for small distances from the coast, with an available infrastructure, a coastline without steep slopes with free access to the coastline. All this greatly complicates the installation and operation of the system, and taking measurements at distances of more than $500 \mathrm{~m}$ from the coast becomes a difficult task in practice. Therefore, the possibility of autonomous operation of the laser-interference complex is a necessity. However, as practical experience has shown, the transition to a completely autonomous operation with the placement of registration means and power sources in the instrument case was not advisable. Worsening the achieved characteristics of the weight and size of the device means the complexity of operation, the need to use larger boats and lifting mechanisms. Furthermore, when carrying out measurements near the coastline, the use of a cable line is justified by the absence of restrictions on energy consumption, the duration of operation

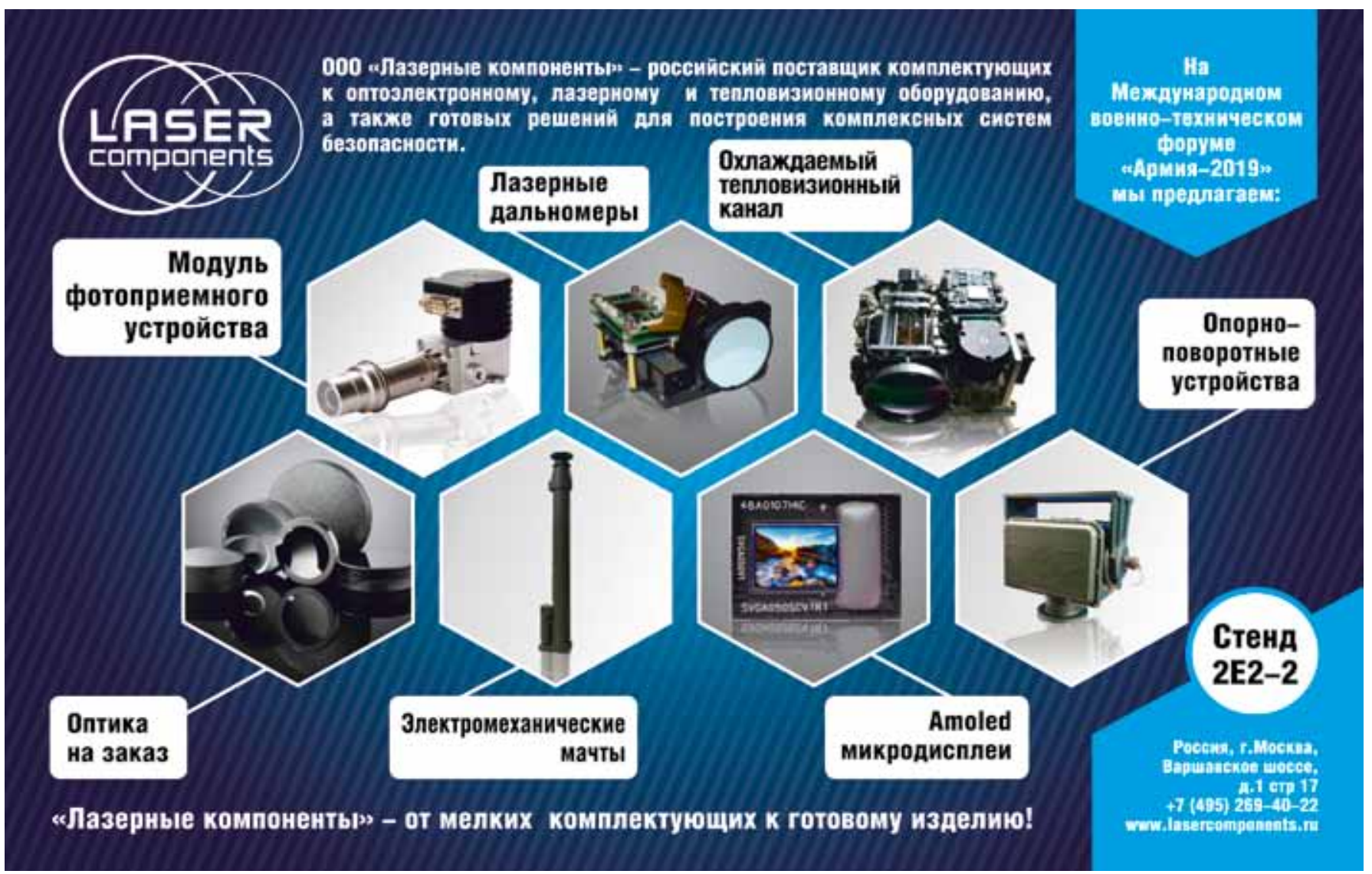

Photonics VOL. 13 № 42019 
научных исследований. Использование данного оборудования позволяет решать задачи по изучению амплитудно-фазовых вариаций колебаний давления, температуры и других параметров в гидросфере в широком частотном диапазоне.

\section{ФИНАНСИРОВАНИЕ}

Работа выполнена при частичной финансовой поддержке грант РФФИ № 18-05-80011_Опасные явления.

\section{СПИСОК ЛИТЕРАТУРЫ}

1. Долгих Г.И., Долгих С. Г., Овчаренко В. В., Чупин В.А., Швец В.А., Яковенко С. В. Лазерный деформограф с точностью на уровне пикометров. Приборы и техника эксперимента. 2013; 2: 138-139.

Dolgikh G. I., Dolgikh S. G., Ovcharenko V.V., Chupin V. A., Shvets V. A., Yakovenko S.V. Laser deformograph with accuracy at the level of picometers. Instruments and experimental technique. 2013; 2: 138-139.

2. Долгих Г.И., Долгих С. Г., Ковалев С. Н., Корень И.А., Новикова О. В., Овчаренко В. В., Окунцева О.П., Швец В.А., Чупин В.А., Яковенко С. В. Лазерный нанобарограф и его применение при изучении баро-деформационного взаимодействия. Физика Земли. 2004; 8: 82.

Dolgikh G. I., Dolgikh S. G., Kovalev S. N., Koren I.A., Novikova O.V., Ovcharenko V.V., Okunceva O. P., Shvets V.A., Chupin V.A., Yakovenko S. V. Laser nanobarograph and its application in the study of baro-deformation interaction. Physics of the Earth. 2004; 8: 82

3. Долгих Г.И., Долгих С.Г., Ковалев С. Н., Швец В.А., Чупин В.А., Яковенко С. В. Лазерный измеритель вариаций давления гидросферы. Приборы и техника эксперимента. 2005; № 6: 56137.

Dolgikh G. I., Dolgikh S. G., Kovalev S. N., Shvets V.A., Chupin V.A., Yakovenko S. V. Laser meter of pressure variations in the hydrosphere. PTE. 2005.; 6: 56137.

4. Долгих Г.И., Будрин С. С., Долгих С. Г., Овчаренко В. В., Чупин В.А., Швец В.А., Яковенко С. В. Морские внутренние волны и атмосферные депрессии Докпады Академии наук. 2015; 462(5): 601.

Dolgikh G. I., Budrin S. S., Dolgikh S. G., Ovcharenko V.V., Chupin V.A., Shvets V. A., Yakovenko S. V. Sea internal waves and atmospheric depressions. Reports of the Academy of Sciences. 2015; 462 (5): 601.

5. Долгих Г.И., Будрин С. С., Долгих С. Г., Закурко А. Г., Косарев О. В., Овчаренко В. В., Плотников А.А., Чупин В.А., Швец В.А., Яковенко С. В. Комплексный пространственно-разнесенный полигон на Дальнем Востоке для геонаблюдений. Измеритепьная техника. 2016; 3:34-36.

Dolgikh G. I., Budrin S. S., Dolgikh S. G., Zakurko A. G., Kosarev O.V., Ovcharenko V.V., Plotnikov A. A., Chupin V. A., Shvets V. A., Yakovenko S. V. Complex spatially separated polygon in the Far East for geo-observations. Measuring equipment. 2016; 3: 34-36.

6. Долгих Г.И., Будрин С. С., Долгих С. Г., Ковалев С. Н., Плотников А.А., Чупин В.А., Швец В.А., Яковенко С. В. Лазерно-интерференционные системы измерения распределения гидростатического давления. Подводные исспедования и робототехника. 2011; 1(1): 49-58.

Dolgikh G. I., Budrin S. S., Dolgikh S. G., Kovalev S. N., Plotnikov A. A., Chupin V.A. Shvets V.A., Yakovenko S.V. Laser-interference systems for measuring the distribution of hydrostatic pressure. Underwater research and robotics. 2011; 1 (17): 49-58.

7. Долгих Г. И., Долгих С. Г., Чупин В.А., Яковенко С. В. Лазерный гидрофон на основе зеленого лазера LCM-S111. Приборы и техника эксперимента. 2013; 5: 140-141. Dolgikh G. I., Dolgikh S. G., Chupin V.A., Yakovenko S. V. Laser hydrophone based on a green laser LCM-S117. Instruments and experimental technique. 2013; (5): 140-141.

8. Долгих Г.И., Ковалев С. Н., Швец В.А., Яковенко С. В. Цифровая система регистрации лазерно-интерференционных установок. Приборы и техника эксперимента. 2008: 5: 158-159

Dolgikh G. I., Kovalev S. N., Shvets V. A., Yakovenko S. V. Digital registration system of laser-interference installations. Instruments and experimental technique. 2008; 5: 158-159.

9. Ландау Л. Д., Лифшиц Е. М. Теоретическая физика. Т. VII. Теория упругости. М.: Наука. 1987.

Landau L. D., Lifshits E. M. Theoretical physics. T. VII. Theory of elasticity. M.: Science. 1987. time, the ability to instantly receive any amount of information recorded by the sensors, and the simplification of telemetry. In order to simultaneously preserve these advantages and ensure the possibility of working both with and without a cable line, an autonomation container was developed (Fig. 3).

The container has batteries (lithium-ion 4S electric power battery with a capacity of $7965 \mathrm{Wh}$ ), blocks for matching and stabilizing electrical circuit parameters, as well as a microcomputer with a solid-state drive for recording information from the device. The container is connected to the pressure connector of the device, which is usually used for the shore cable. The autonomous operation time of the device is more than 6 days, which, taking into account the significance of energy consumption by the gas laser, the recording system, pressure and temperature meters, and communication systems operating at high frequencies, is a very good indicator. Successful battery life tests were conducted for 145 hours. Fig. 4 shows a plot of the recording, demonstrating pressure fluctuations during wind disturbances. The ordinate is the voltage at the output of the recording system, which is proportional to the measured pressure. Conversion factor $0,25 \mathrm{~V} / \mathrm{Pa}$. The abscissa is time. Installation depth of the device is $12 \mathrm{~m}$.

The digital temperature sensors installed in the device allow the adjustment of the interferometer readings taking into account temperature variations. This is important because a change in the temperature inside the instrument leads to a change in the length of the reference "arm" due to thermal expansion of the interferometer parts. An external sensor provides information on the temperature field outside the instrument. In this model of the device, it is necessary to adjust the output signal of the interferometer detection system by $-3.305 \mathrm{~V}$ for each step of measuring the thermal sensor, i.e. by $0.0625^{\circ} \mathrm{C}$. The voltage value was chosen empirically during the tests. The function of correcting the interferometer reading was included in the measurement processing software.

The tests of the developed ALPFM were successful and the device can be used for scientific research. The use of this equipment allows to solve the problems for the study of amplitude-phase variations of pressure fluctuations, temperature tours and other parameters in the hydrosphere in a wide frequency range.

\section{FUNDING}

This work was partially funded by RFBR grant No. 18-05-80011_Hazardous phenomena. 


\section{МОСКВА, ВДНХ, ПАВИЛЬОН №75 \\ 22-25 ОКТЯБРя 2019}

XXIII МЕЖДУНАРОДНАЯ ВЫСТАВКА
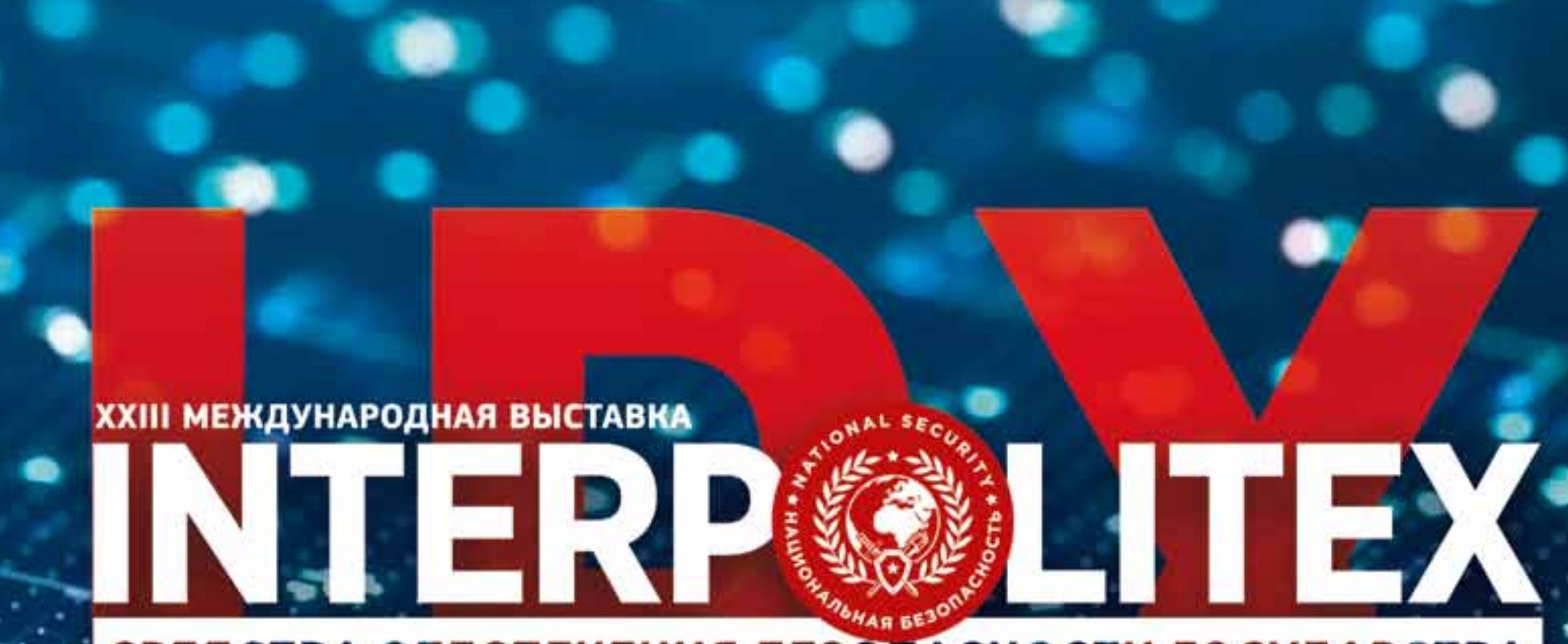

\section{СРЕДСТВА ОБЕСПЕЧЕНИЯ БЕЗОПАСНОСТИ ГОСУДАРСТВА}

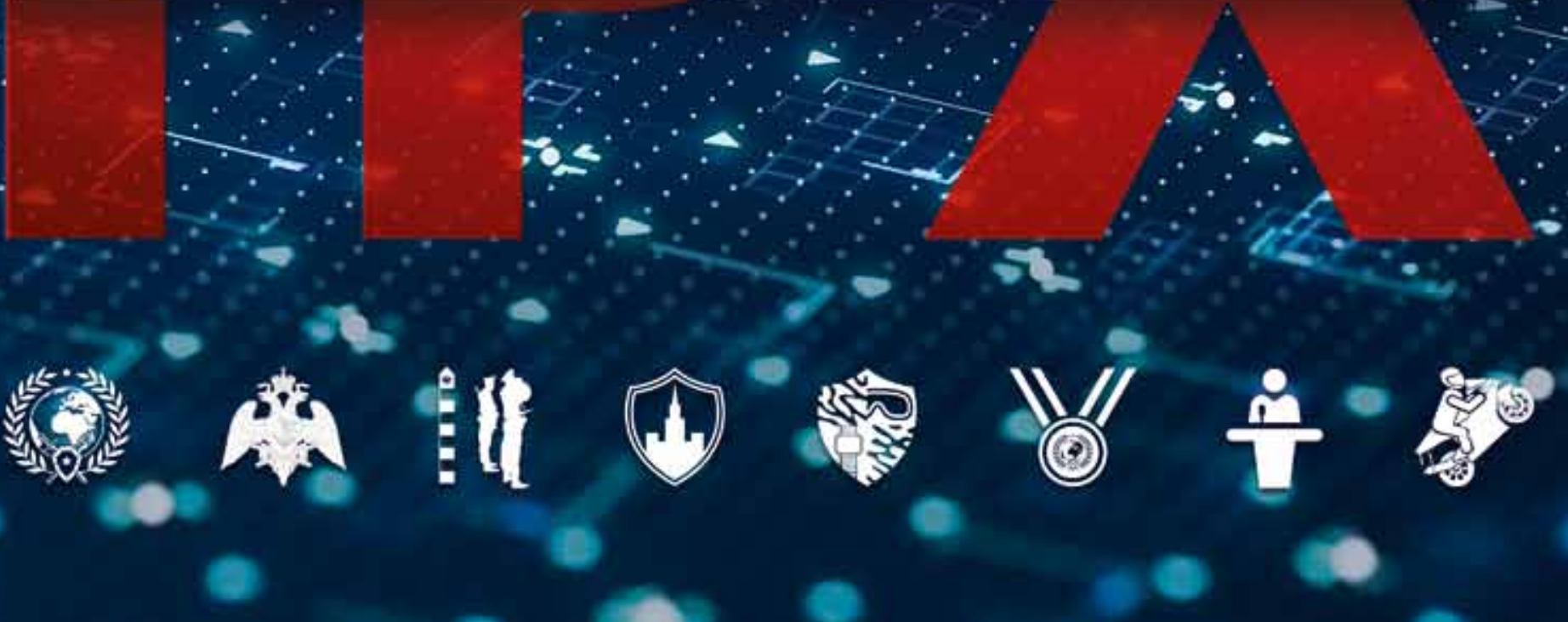

\section{WWW.INTERPOLITEX.RU}

OРГАНИЗАТОРЫ

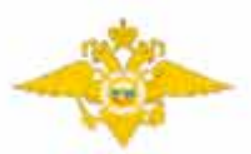

мвд России

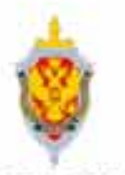

ФСБ РОССИИ

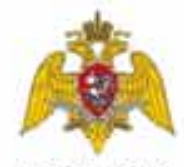

РОСТВАРДИЯ
OPTAHИЗАTOP ВЫСТАВКИ КГРАНИLА

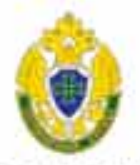

ПС ФСБ РОССи
ЭКСПОНЕНТ-КООРДИНАТОР ОТ МВД РОССИИ

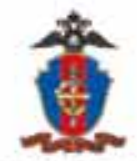

ФКУ \&HกO \&CTИC. МВД РОССИИ
REHEPANЬHЫЙ
УСТРОИTЕ

IForher

$3 A O=O B K=5 И 3 O H *$ 